\title{
APLIKASI PENJUALAN POINT OF SALE (POS) MENGGUNAKAN BARCODE PADA KOPERASI BINA KASIH SEJAHTERA BERBASIS DESKTOP DENGAN METODE FIRST IN FIRST OUT (FIFO)
}

\author{
I Komang Agus Bawa Wahyudi ${ }^{1)}$ I.G.N. Alit Widana Putra ${ }^{2)}$ Aulia Iefan Datya ${ }^{3)}$ \\ Program Studi Teknik Informatika ${ }^{1)}$ 2) \\ Program Studi Sistem Informasi ${ }^{3)}$ \\ Fakultas Ilmu Kesehatan Sains dan Teknologi, Universitas Dhayan Pura, Bali. \\ agusbawa@gmail.com ${ }^{1)}$ alitwp@gmail.com²) iefandatya@undhirabali.ac.id ${ }^{3)}$
}

\begin{abstract}
Information technology plays an important role in various institutions, one of which is a cooperative. Cooperative Bina Kasih Sejahtera Dhyana Pura University is a cooperative that has two business fields specifically trading business and savings and loan. However, there are some problem that are often encountered in sales activities, procurement and reporting. The problem occurs in the recording process that is still done manually. So often spend a lot of books every time there is a transaction and less accuracy in the data collection of transactions and procurement of goods, goods and transactions are not accurate and impact on the process of making a profit statement.This study uses several methods, descriptive used in the completion of data both in literature and field studies. The waterfall method used to analyze and design applications where the process consists of software development, making it easier to understand. The FIFO (First In First Out) method is implemented in the report generation process in the application.The result of this research is Point Of Sale Application (POS) Using Barcode In Cooperative Bina Kasih Sejahtera Based On Dekstop With First In First Out (FIFO) Method in making report, making it easier for administrators or officers in serving customers in terms of transactions.
\end{abstract}

Keywords: Dhyana Pura University, Point of Sale, cooperative, FIFO.

\begin{abstract}
ABSTRAK
Teknologi informasi sangat berperan penting dalam berbagai macam instansi, salah satunya adalah koperasi. Koperasi Bina Kasih Sejahtera Universitas Dhyana Pura merupakan koperasi yang mempunyai dua bidang usaha yaitu usaha dagang dan simpan pinjam. Akan tetapi, terdapat beberapa masalah yang sering dihadapi dalam kegiatan penjualan, pengadaan barang dan pelaporan. Masalah terjadi pada proses pencatatan yang masih dilakukan dengan manual. Sehingga sering kali menghabiskan banyak buku setiap kali ada transaksi serta ketelitian yang kurang dalam pendataan transaksi dan pengadaan barang, data barang dan transaksi tidak akurat dan berdampak pada proses pembuatan laporan keuntungan.Penelitian ini menggunakan beberapa metode diantaranya, metode deskriptif yang digunakan dalam pengumpulan data baik secara literatur maupun studi lapangan. Metode Waterfall dipakai untuk menganalisis dan perancangan aplikasi yang dimana tahapannya mengambil kegiatan dasar yang digunakan dalam hampir semua pengembangan prangkat lunak, sehingga dapat lebih mudah untuk dipahami. Metode FIFO (First In First Out) diimplementasikan dalam proses pembuatan laporan pada aplikasi.Hasil penelitian ini adalah Aplikasi Point Of Sale (POS) Menggunakan Barcode Pada Koperasi Bina Kasih Sejahtera Berbasis Dekstop Dengan Metode First In First Out (FIFO) dalam pembuatan laporannya, sehingga memudahkan pengurus atau petugas dalam melayani konsumen dalam hal bertransaksi.
\end{abstract}

Kata Kunci: Universitas Dhyana Pura, Point of Sale, koperasi, FIFO. 


\section{PENDAHULUAN}

Teknologi informasi berperan penting dalam memperbaiki kualitas suatu instansi. Penggunaannya tidak hanya sebagai proses otomatisasi terhadap akses informasi, tetapi juga menciptakan akurasi, kecepatan, dan kelengkapan sebuah sistem yang terintegrasi, sehingga semakin diminati oleh berbagai instansi, baik instansi pemerintah maupun instansi swasta. Penggunaan teknologi informasi sudah mulai juga digunakan pada koperasi-koperasi saat ini, dengan komputerisasi diharapkan dapat membantu dalam kecepatan pengolahan data atau penanganan informasi pada koperasi sehingga akan mempercepat proses dalam menyajikan informasi secara akurat dan cepat pada koperasi itu sendiri.

Koperasi Bina Kasih Sejahtera Universitas Dhyana Pura merupakan salah satu koperasi yang mempunyai dua bidang usaha yaitu usaha dagang dan simpan pinjam. Usaha dagang atau yang biasa disebut "Unit Koperasi" ini menjual barang keperluan sehari-hari secara retail. Unit koperasi memiliki kegiatan jual-beli yaitu pencatatan barang, pencatatan transaksi, dan pembuatan laporan. Hasil dari penjualan unit koperasi tersebut digunakan untuk peminjaman uang dan pemesanan barang yang telah habis terjual untuk dijual kembali. Pada koperasi Bina Kasih Sejahtera terdapat masalah yang sering dihadapi dalam kegiatan penjualan, pengadaan barang, dan pelaporan. Pada penjualan dan pengadaan barang, masalah yang terjadi adalah pencatatan yang dilakukan masih menggunakan pencatatan manual sehingga banyak menghabiskan buku tulis untuk penggunaan dalam setiap transaksi serta ketelitian yang kurang dalam pendataan transaksi dan pengadaan barang, sehingga data-data barang dan transaksi tidak akurat yang akan berdampak pada pembuatan laporan keuntungan pada Koperasi Bina Kasih Sejahtera.

Dalam kajian ini koperasi harus dapat mengurangi dan meminimalisasi kesalahan-kesalahan yang berdampak buruk terhadap keuntungan atau laba yang diperoleh. Untuk itu diperlukan sebuah solusi untuk membantu menyelesaikan masalah yang ada pada Koperasi Bina Kasih Sejahtera yang bisa diterapkan guna mengatasi masalah tersebut yaitu dengan memanfaatkan teknologi dan sistem informasi yang dimana dapat digunakan oleh Koperasi Bina Kasih Sejahtera untuk mengetahui jumlah kuantitas persediaan serta keuntungan atau laba yang ada dalam unit koperasi mereka dengan menggunakan metode First In First Out (FIFO). Dengan adanya penerapan sistem in- formasi dengan metode First In First Out (FIFO), data yang ada menjadi lebih terkomputerisasi dengan baik antara laporan data barang dan penjualan, sehingga data yang diperoleh akan lebih akurat.

\section{TINJAUAN PUSTAKA \\ Konsep Dasar Sistem}

Sistem merupakan hal yang penting untuk membuat serta merancang sistem informasi. Di dalam suatu organisasi atau instansi pasti memiliki sistem informasi yang dimana digunakan untuk melihat, mengumpulkan, menyimpan, dan menyalurkan informasi. Sistem informasi dapat terbentuk dikarenakan adanya suatu kebutuhan akan informasi yang terus meningkat yang dibutuhkan oleh pengambil keputusan.

\section{Sejarah Koperasi}

Koperasi lahir pada permulaan abad ke-19 sebagai reaksi padasistem liberaisme ekonomi yang pada waktu itu segolongan pemilik-pemilik modal menguasai masyakarat. Koperasi pada mulanya tumbuh dengan munculnya pikiran-pikiran tentang pembaharuan masyarakat yang terutama dipelopori oleh aliran gerakan sosialis aliran ini sangat berpengaruh dalam pertumbuhan koperasi karena :

1. Koperasi membentuk suatu dasar bagi organisasi kemasyarakatan yang berbeda dengan bentuk cita-cita sistem kapitalisme yang berkuasa dibanyak bagian barat pada waktu itu. Motif utama sistem kapitalis adalah laba yang sebesarbesarnya sehingga sistem ini menimbulkan akibat yang berat bagi kaum buruh karena mereka menjadi kaum yang tertindas. Oleh karena itu gerakan sosialis berusaha melenyapkan penderitaan ini.

2. Munculnya perkumpulan koperasi dianggap oleh gerakan sosialis sebagai cara praktis bagi kaum buruh dan produsen kecil untuk melepaskan diri dari penindasan kaum kapitalis.

Namun kenyataanya semakin lama koperasi menempuh jalan berbeda untuk mencapai tujuan. Bahkan sekarang koperasi tumbuh subur di negara-negara yang menganut sistem kapitalis dan kemudian koperasi menjadi organisasi pengimbang yang dapat melenyapkan keburukan-keburukan sistem kapitalis itu sendiri. 
Jenis-jenis Koperasi

Koperasi Berdasarkan Jenisnya ada 4, yai-tu :

1. Koperasi Produksi (Koperasi Produksi melakukan usaha produksi atau menghasilkan barang).

2. Koperasi Konsumsi (Koperasi Konsumsi menyediakan semua kebutuhan para anggota dalam bentuk barang).

3. Koperasi Simpan Pinjam (Koperasi Simpan Pinjam melayani para anggotanya untuk menabung dengan mendapatkan imbalan).

4. Koperasi Serba Usaha (Koperasi Serba Usaha (KSU) terdiri atas berbagai jenis usaha).

\section{Berdasarkan Keanggotaannya:}

1. Koperasi Pegawai Negeri (Koperasi ini beranggotakan para pegawai negeri baik pegawai pusat maupun daerah).

2. Koperasi Pasar (Koppas) (Koperasi pasar beranggotakan para pedagang pasar).

3. Koperasi Unit Desa (KUD) (Koperasi Unit Desa beranggotakan masyarakat pedesaan. KUD melakukan kegiatan usaha bidang ekonomi terutama berkaitan dengan pertanian atau perikanan (nelayan).

4. Koperasi Sekolah (Koperasi sekolah beranggotakan warga sekolah yaitu guru, karyawan, dan siswa).

\section{Berdasarkan Tingkatannya:}

1. Koperasi Primer (Koperasi primer merupakan koperasi yang beranggotakan orang-orang).

2. Koperasi Sekunder (Koperasi sekunder merupakan koperasi yang beranggotakan beberapa koperasi).

\section{Berdasarkan Fungsinya:}

1. Koperasi Konsumsi (didirikan untuk memenuhi kebutuhan umum sehari-hari para anggotanya).

2. Koperasi Jasa (adalah untuk memberikan jasa keuangan dalam bentuk pinjaman kepada para anggotanya).

3. Koperasi Produksi (Bidang usahanya adalah membantu penyediaan bahan baku, penyediaan peralatan produksi, membantu memproduksi jenis barang tertentu serta membantu menjual dan memasarkannya hasil produksi tersebut).

\section{Point of Sale (POS)}

Point of sale atau disingkat POS secara umum dapat diartikan sebagai sebuah sistem yang memungkinkan diadakannya proses transaksi. POS dapat digunakan di semua transaksi penjualan seperti restoran, supermarket, hotel, dan toko-toko retail. Karena itu, POS juga dapat diartikan sebagai proses pelayanan transaksi dalam sebuah toko retail. Dari semua pengertian yang dijelaskan tersebut, maka dapat diambil kesimpulan bahwa point of sale dapat diartikan sebagai sebuah sistem yang memungkinkan diadakannya transaksi yang didalamnya termasuk juga penggunaan mesin kasir. Menurut Rokhman (2012), perangkat lunak point of sale (POS) adalah perangkat lunak yang banyak digunakan pada usaha retail seperti swalayan, mini market, apotek, cafe, dan lain-lain. Secara umum proses-proses yang biasanya digunakan di setiap sistem point of sale yang terdapat di perusahaan-perusahaan adalah sebagai berikut :

1. Point of sale (transaksi penjualan)

2. Inventory control (Pengendalian persediaan barang)

3. Pembacaan barcode

4. Manajemen stook

5. Retur penjualan

6. Pelaporan

\section{Barcode}

Barcode secara harfiah berarti kode berbentuk garis. Barcode yang dikenal orang umumnya tercetak pada kemasan produk suatu barang. Atau kita sering melihatnya ketika petugas kasir minimarket menscan kode-kode berbentuk garis saat kita selesai berbelanja. Kita hanya mengenalnya secara sekilas tapi tidak begitu tahu maksud kegunaannya.

\section{Pengertian Metode First In First Out (FIFO)}

Metode First In First Out (FIFO) merupakan cara penilaian persediaan yang digunakan oleh perusahaan untuk menentukan harga pokok persediaan. Metode First In First Out (FIFO) ini digunakan untuk mengetahui jumlah persediaan yang akan dijual kepada konsumen atau pembeli serta untuk mengetahui jumlah persediaan akhir barang yang diperoleh pada akhir periode. Pada umumnya metode ini dipakai pada perusahaan-perusahaan yang men- 
jual produk yang mudah rusak serta mudah ketinggalan zaman seperti buah-buahan, sayuran, dan lain-lain.

Metode First In First Out (FIFO) ini diartikan sebagai : Metode First In First Out (FIFO) adalah metode yang membebankan biaya bahan baku persediaan sesuai dengan harga persediaan tertua digudang (Carter Usry, 2004 : 303).

Sedangkan pengertian lain menurut ahli yang dapat penulis kemukakan adalah First In First Out (FIFO) adalah metode masuk pertama, keluar pertama yang menentukan biaya bahan baku dengan anggapan bahwa harga pokok per satuan bahan baku yang pertama masuk dalam gudang, digunakan untuk menentukan harga bahan baku yang pertama kali dipakai (Mulyadi, 1999 : 312).

\section{Pengertian Laba}

Laba atau keuntungan dapat didefinisikan dengan dua cara. Laba dalam ilmu ekonomi murni didefinisikan sebagai peningkatan kekayaan seorang investor sebagai hasil penanam modalnya, setelah dikurangi biaya-biaya yang berhubungan dengan penanaman modal tersebut (termasuk di dalamnya, biaya kesempatan). Sementara itu, laba dalam akuntansi didefinisikan sebagai selisih antara harga penjualan dengan biaya produksi. Perbedaan diantara keduanya adalah dalam hal pendefinisian biaya (Wikipedia).

Menurut (Amin Widjaja Tunggal, 1996 : 87), Adanya perubahan didalam perolehan laba pada dasarnya adalah disebabkan oleh dua faktor yaitu faktor penjualan dan faktor harga pokok penjualan. Terdapat empat cara yang digunakan oleh perusahaan atau koperasi dalam mengembangkan laba atau keuntungan diantaranya :

1. Menaikan harga jual per unit

2. Menurunkan biaya variabel per unit

3. Menurunkan biaya non variabel

4. Menaikan volume penjualan

Berdasarkan pengertian di atas dapat disimpulkan bahwa laba adalah kelebihan pendapatan di atas biaya sebagai imbalan menghasilkan barang dan jasa selama satu periode akuntansi.

\section{Pengaruh Penggunaan Metode FIFO Terhadap Laba}

Menurut (Henry Simamora, 2000 : 275), dewasa ini perekonomian dunia tengah dilanda inflasi yang berarti bahwa harga-harga melonjak terus. Manakala biaya pembelian meningkat, metode First In First Out (FIFO) menggunakan metode yang lebih lama kepada biaya pokok penjualan dan biaya yang paling akhir kepada barang-barang yang ada dalam persediaan. Dalam kondisi seperti ini, metode First In First Out (FIFO) menghasilkan kontribusi negatif terhadap laporan laba rugi karena biaya perolehan persediaan barang dagangan yang lama dan relatif lebih murah (sebagai bagian dari harga pokok penjualan), dikaitkan dengan penjualan terkini dan relatif lebih tinggi nilainya.

Dengan mengenakan biaya yang lebih rendah kepada harga pokok penjualan, metode First In First Out (FIFO) biasanya mengakibatkan perusahaan melaporkan laba yang tinggi dibandingkan bila menggunakan metode persediaan lainnya. Beberapa perusahaan lebih menyukai menggunakan metode First In First Out (FIFO) untuk tujuan pelaporan keuangannya karena tujuan mereka adalah memperlihatkan angka laba yang lebih banyak ketimbang yang semestinya akan mengakibatkan pajak terutang yang lebih tinggi daripada yang seharusnya.

Metode First In First Out (FIFO) cenderung menetapkan terlalu tinggi tingkat profitabilitas perusahaan, pendapatan didasarkan pada kondisi pasar sekarang. Dengan mengurangkan pendapatan dengan biaya pokok penjualan yang berdasarkan harga yang lebih lama (atau lebih rendah), maka laba kotor perusahaan akan disajikan terlalu besar secara konsisten.

\section{MicrosoftWindows}

Microsoft Windows atau yang lebih dikenal dengan sebutan Windows adalah keluarga sistem operasi yang dikembangkan oleh Microsoft, dengan menggunakan antarmuka pengguna grafis. Sistem operasi Windows telah berevolusi dari MS-DOS, sebuah sistem operasi yang berbasis modus teks dan command-line. Windows versi pertama, Windows Graphic Environment 1.0 pertama kali diperkenalkan pada 10 November 1983, tetapi baru keluar pasar pada bulan November tahun 1985, yang di- 
buat untuk memenuhi kebutuhan komputer dengan tampilan bergambar (wikipedia.org).

Saat ini Microsoft Windows boleh di-bilang merupakan sistem operasi yang banyak digunakan pada komputer personal (PC), baik Windows 9x maupun Windows NT dan versiversi Windows terbaru. Sebagai sebuah sistem operasi, Microsoft Windows dilengkapi dengan fasilitas pendukung jaringan komputer dalam bentuk workgroup. Sedangkan dalam bentuk client-server digunakan sistem operasi jaringan MicrosoftWindows NT.

\section{Visual Basic 6.0}

Visual Basic merupakan salah satu dari sekian banyak bahasa pemrograman. Basis dari Visual Basic adalah pemrograman yang bersifat grafis. Perbedaan yang jelas antara program text dan grafis adalah pada program grafis, orientasinya pada obyek. Obyek bisa didefinisikan sebagai suatu benda yang mempunyai "properti/atribut" dan "kejadian atau event".

Dalam Visual Basic, sama juga seperti benda lain, misalnya tombol mempunyai atribut : tinggi, lebar, warna, tulisan dan lain-lain. Kejadian yang berhubungan misalnya click, gotfocus, dan lain-lain. Kita nantinya membuat prosedur atau fungsi untuk tiap kejadian pada tiap obyek yang terlibat dalamaplikasi kita.Pembuatan program secara visual biasanya dibentuk dalam proyek. Proyek ialah kumpulan dari form, module dan kontrol-kontrol yang membentuk program aplikasi. Setiap membuka visual basic secara otomatisvisual basic membuat obyek baru.

\section{METODOLOGI PENELITIAN \\ Lokasi Penelitian}

Penelitian ini bertempat di Koperasi Bina Kasih Sejahtera Universitas Dhyana Pura, yang berlokasi di Jalan Raya Padang Luwih Tegaljaya Dalung Kuta Utara, Bali. Sejarah singkat Koperasi Bina Kasih Sejahtera yang berkedudukan di Universitas Dhyana Pura tepatnya di Jalan Raya Padang Luwih, Badung. Koperasi Bina Kasih Sejahtera didirikan berdasarkan kuasa rapat pembentukan untuk mendirikan koperasi oleh karyawan Universitas Dhyana Pura pada tahun 1999 dan terdaftar pada tanggal 14 Januari 1999. Tujuan utamanya adalah agar terbentuk suatu badan usaha yang berperan untuk membina dan mengembangkan kesejahteraan pegawai di lingkungan Universitas Dhyana Pura. Disamping itu, pendirian Kope- rasi Bina Kasih Sejahtera juga bertujuan untuk menyelenggarakan bantuan dari pimpinan Universitas dan instansi lain untuk meningkatkan kesejahteraan pegawai yang dilaksanakan oleh koperasi.

\section{Metode Pengumpulan Data \\ Studi Literatur}

Studi literatur adalah pengumpulan data melalui buku-buku, jurnal, halaman web, makalah serta bacaan lain yang sesuai dengan topik yang dibahas.

\section{Studi Lapangan}

Studi lapangan adalah pengumpulan data dengan dua cara yaitu:

1. Observasi

Tahap observasi adalah pengumpulan data dengan mengadakan penelitian dan peninjauan langsung ke Koperasi Bina Kasih Sejahtera.

2. Wawancara

Pada metode pengumpulan data ini penulis mewancarai seseorang yang ahli dalam bidangnya atau melakukan diskusi dengan seseorang yang mengerti terhadap materi bahasan agar mendapatkan bahan masukan dan data pendukung dalam penyusunan skripsi ini.

\section{Metode Analisis Dan Perancangan}

Metode penelitian yang akan digunakan dalam perancangan aplikasi Point Of Sale (POS) ini menggunakan metode waterfall, Karena metode ini terdiri dari tahap-tahap yang memberikan kemudahan dan mudah dipahami.

\section{Analisis Masalah Yang Dihadapi}

Tabel 1. Analisis Masalah

\begin{tabular}{|l|l|c|}
\hline No & \multicolumn{1}{|c|}{ Permasalahan } & Pihak \\
\hline 1. & $\begin{array}{l}\text { Sistem yang berjalan sa- } \\
\text { at ini masih manual den- } \\
\text { gan sistem transaksi ba- } \\
\text { rang secara tetulis maka } \\
\text { akan menghabiskan } \\
\text { waktu yang cukup ban- }\end{array}$ & \\
\hline 2. & $\begin{array}{l}\text { Pada perhitungan data } \\
\text { yak. }\end{array}$ & \\
& $\begin{array}{l}\text { transaksi masih meng- } \\
\text { gunakan manual (kalku- } \\
\text { lator), sering terjadi ke- } \\
\text { salahan perhitungan } \\
\text { uang dalam melakukan }\end{array}$ & Koperasi \\
\hline
\end{tabular}




\begin{tabular}{|l|l|c|}
\hline & transaksi. & \\
\hline 3. & $\begin{array}{l}\text { Penyimpanan data ba- } \\
\text { rang, data transaksi pen- } \\
\text { jualan, data transaksi } \\
\text { pembelian masih tersim- } \\
\text { pan didalam buku. }\end{array}$ & Koperasi \\
\hline 4. & $\begin{array}{l}\text { Didalam pencarian data } \\
\text { seorang pengelola sering } \\
\text { mengeluh karena data } \\
\text { yang tersimpan didalam } \\
\text { arsip sangat banyak dan } \\
\text { akan membutuhkan } \\
\text { waktu yang lama. }\end{array}$ & Koperasi \\
\hline 5. & $\begin{array}{l}\text { Didalam penyajian lapo- } \\
\text { ran yang diminta oleh } \\
\text { pimpinan koperasi untuk } \\
\text { mengevaluasi penjualan } \\
\text { sangat lama dikarnakan } \\
\text { menggunkan sistem ma- } \\
\text { nual. }\end{array}$ & \\
\hline
\end{tabular}

\section{Analisis Sistem Yang Sedang Berjalan}

Tahap analisis yang sedang berjalan ini akan menguraikan mengenai Deskripsi prosedur, serta evaluasi dari sistem yang sedang berjalan tentang pembelian dan penjualan barang di Koperasi Bina Kasih Sejahtera. Analisis sistem yang sedang berjalan bertujuan untuk mengetahui lebih jelas bagaimana cara kerja sistem tersebut dan masalah yang dihadapi sistem untuk dapat dijadikan landasan usulan perancangan analisis sistem yang sedang berjalan yang dilakukan berdasarkan urutan kejadian yang ada.

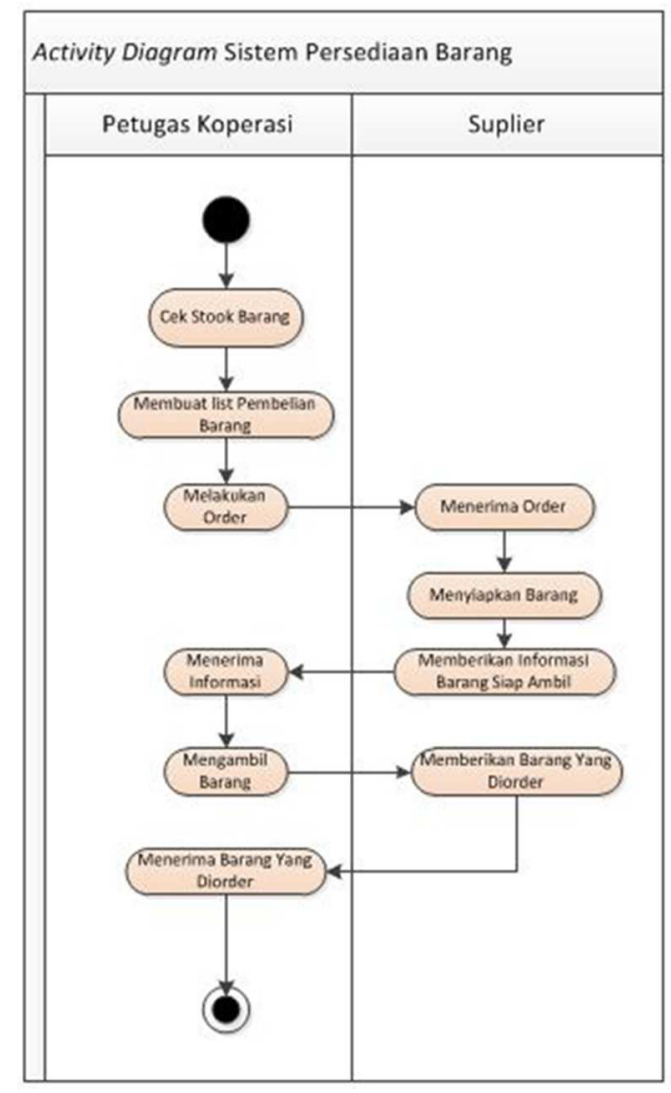

Gambar 1. Activity Diagram Persedian Barang

Keterangan Gambar 1 :

a. 2 Swimlane, yaitu Petugas Koperasi, Suplier.

b. 1 Initial Node, sebagai awal objek

c. 10 Action dari sistem yang mencerminkan eksekusi dari suatu aksi yaitu cek stok barang, membuat list pembelian barang, melakukan order, menerima order, menyiapkan barang, memberikan informasi barang siap ambil, memberikan barang yang di order, menerima informasi, mengambil barang, menerima barang yang di order.

d. 1 Final Node, sebagai objek yang diakhiri. 


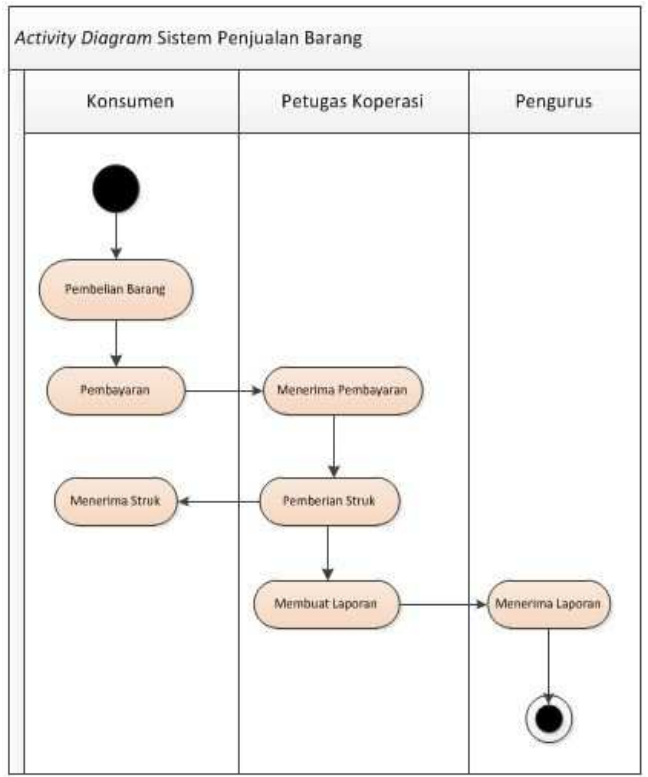

Gambar 2. Activity Diagram Penjualan Barang

Keterangan Gambar 2 :

a. 3 Swimlane, yaitu Konsumen, Petugas Koperasi, Pengurus.

b. 1 Initial Node, sebagai awal objek

c. 7 Action dari sistem yang mencerminkan eksekusi dari suatu aksi yaitu Pembelian barang, pembayaran, menerima pembayaran, pemberian struk, menerima struk, membuat laporan, menerima laporan.

d. 1 Final Node, sebagai objek yang diakhiri.

\section{Data Flow Diagram (DFD)}

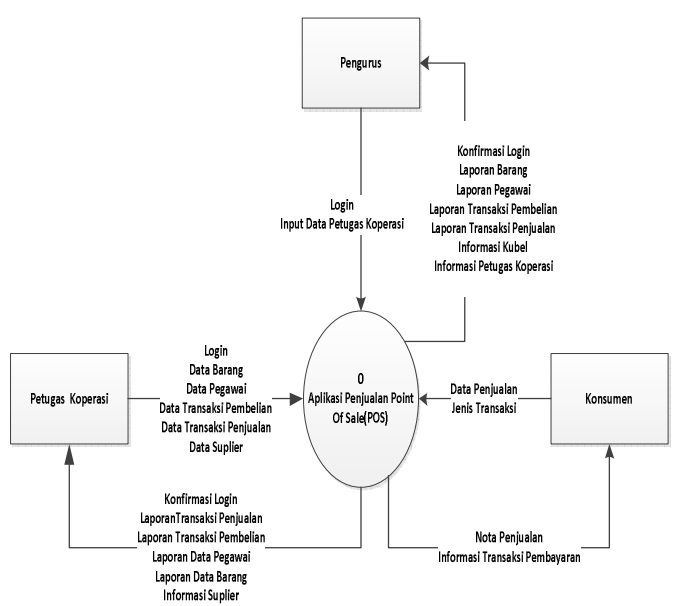

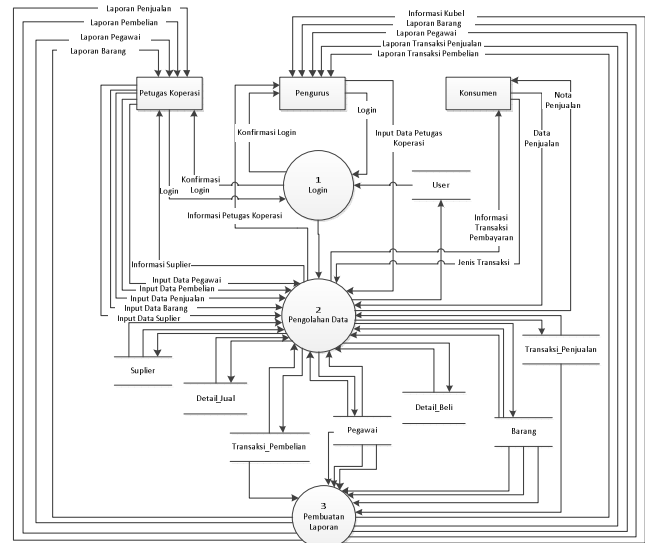

Gambar 4. DFD Level 0

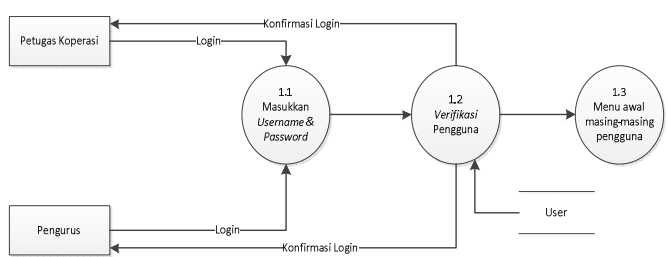

Gambar 5. DFD Level 1 (Proses 1)

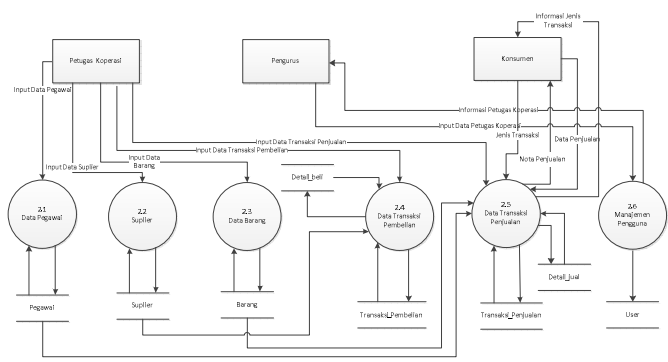

Gambar 6. DFD Level 1 (Proses 2)

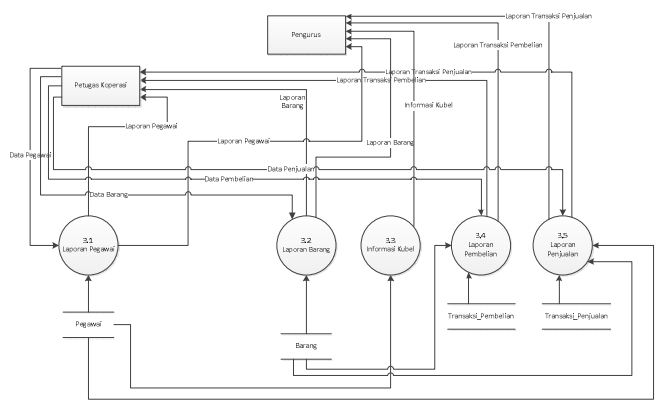

Gambar 7. DFD Level 1 (Proses 3)

Gambar 3. Diagram Konteks 


\section{Entity Relationship Diagram (ERD)}

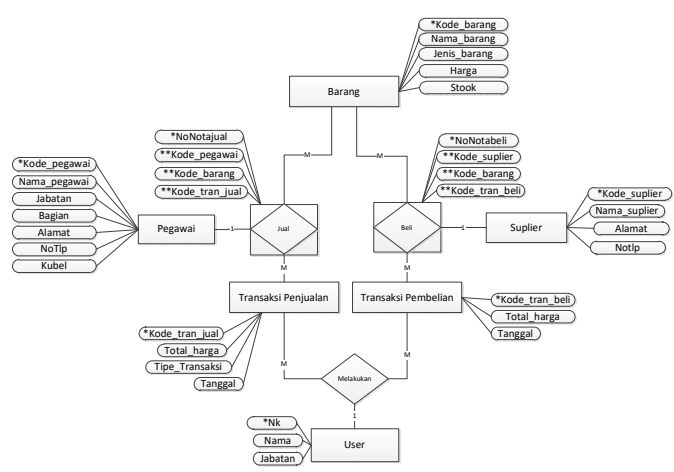

Gambar 8. ERD Aplikasi Point Of Sale (POS) Koperasi

\section{Struktur Menu}

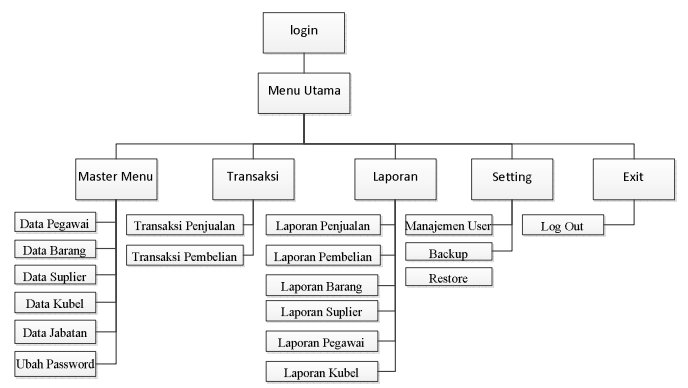

Gambar 9. Struktur Menu Aplikasi Point Of Sale (POS) Koperasi

\section{IMPLEMENTASI SISTEM}

Pada tahap ini hasil dari tahap-tahap analisis dan perancangan yang telah dilakukan akan dituangkan kedalam sebuah program. Program ini adalah Aplikasi Point Of Sale (POS) Koperasi Bina Kasih Sejahtera. Sedangkan untuk pemrograman dalam sistem ini menggunakan aplikasi Visual basic 6.0

\section{Kebutuhan Prangkat Lunak}

Pada prangkat lunak pendukung menjelaskan prangkat lunak apa saja yang dibutuhan untuk membangun aplikasi point of sale. Berikut adalah perangkat lunak yang digunakan dalam pembuatan aplikasi ini adalah sebagai berikut:

1. Sistem Operasi Windows 7 Ultimate.

2. DBMS menggunakan Microsoft Access 2007

3. Adobe Photoshop CS 3.

4. Aplikasi Visual Basic 6.0

\section{Kebutuhan Prangkat Keras}

Selain perangkat lunak (Software) juga dibutuhkan keberadaan perangkat keras (Hardware) untuk membangun aplikasi point of sale, hal ini untuk mendukung agar program ini dapat berjalan dengan baik, berikut spesifikasi perangkat keras yang digunakan yaitu:

1. Laptop Lenovo

2. Prossesor AMD A6-6310 1.8GHz

3. RAM 2GB.

4. Hardisk 500 GB.

5. Barcode Reader Datalogic, Quick Scan Lite.

6. Printer Kasir Epson TM-U220

\section{Tahapan Pembuatan Aplikasi Menu Utama}

Pada tahap ini dilakukan pembuatan menu utama yang dimana menu utama merupakan halaman yang akan tampil paling awal ketika aplikasi dijalankan. Elemen pada halaman menu seperti background dibuat menggunakan Adobe Photoshop CS 3.Setelah elemen selesai dibuat, buka aplikasi visual basic 6.0 kemudian pilih new $>$ Pilih Standard EXE $>$ open sehingga muncul seperti gambar

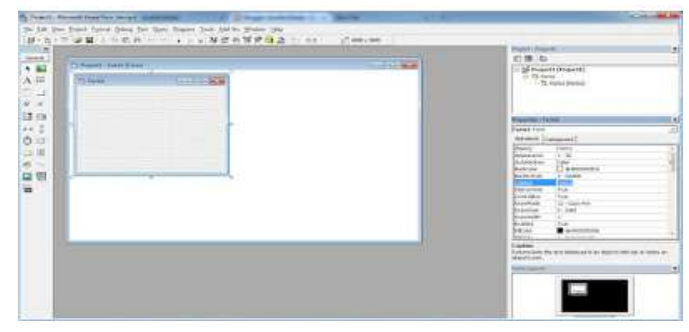

Gambar 10. Tampilan form menu utama

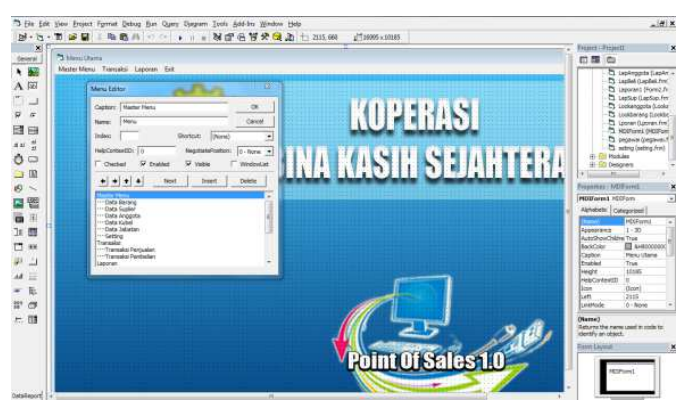

Gambar 11. Tampilan menu editor 
IMPLEMENTASI ANTARMUKA

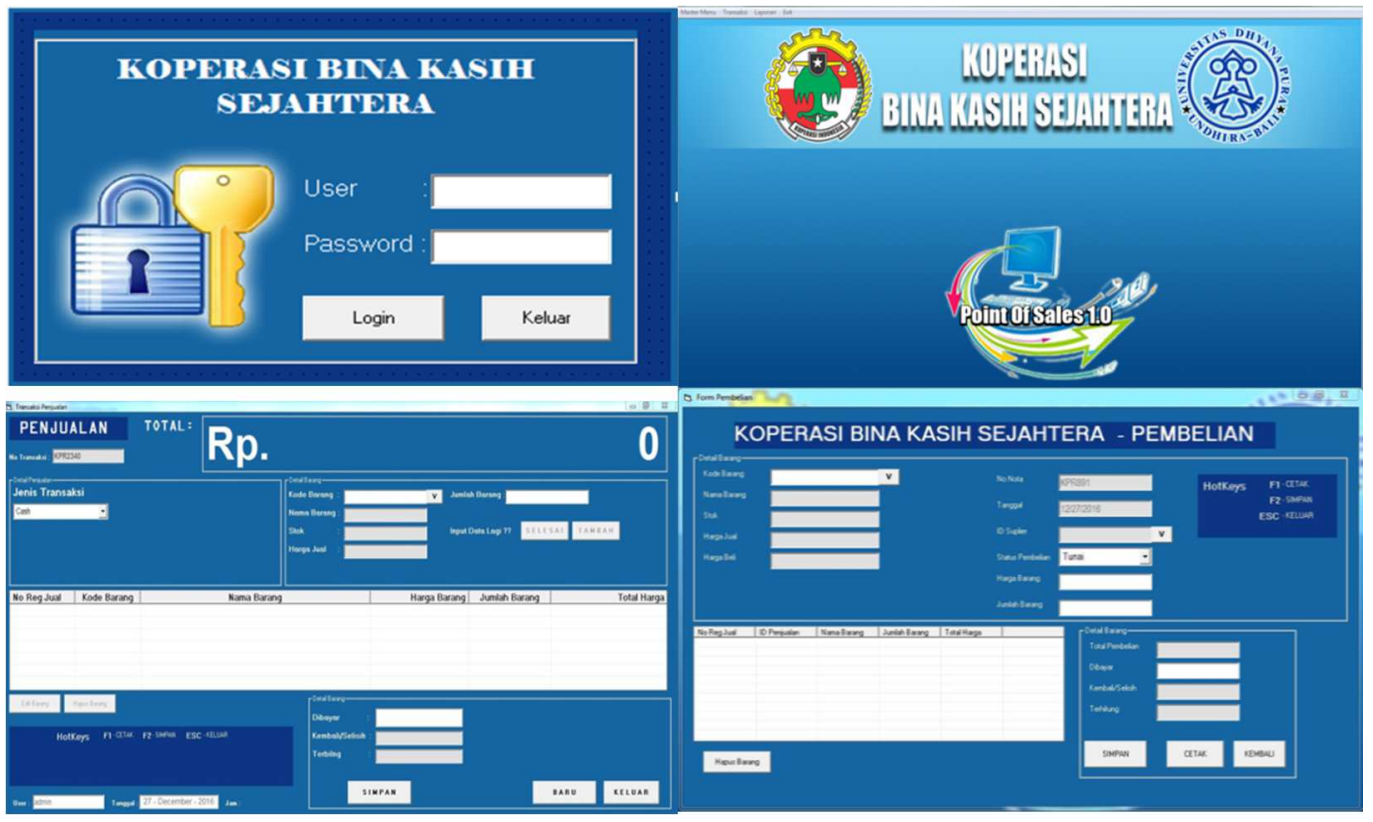

Gambar 12. Tampilan Antarmuka Aplikasi

\section{SIMPULAN}

Dari hasil penelitian yang dilakukan pada Koperasi Bina Kasih Sejahtera, maka penyusun menarik beberapa kesimpulan bahwa:

- Membuat desain sistem yang mampu mencakup proses penjualan, pengadaan, dan pencatatan barang.

- $\quad$ Aplikasi penjualan Point Of Sale (POS) ini akan lebih memudahkan proses penjualan dan pengadaan barang pada Koperasi Bina Kasih Sejahtera yang dapat diakses, dimodifikasi, dan dievaluasi untuk memudahkan pengurus atau karyawan dalam melayani konsumen dalam hal bertransaksi.

\section{DAFTAR PUSTAKA}

[1] Al Fatta, Hanif. 2007. Analisis dan Perancangan Sistem Informasi. Yogyakarta : ANDI.

[2] Dharwiyanti, Sri. (2003). PengantarUnified Modeling Language (UML). Bandung: Informatika. Hlm. 1-2.

[3] Hendar. 2010. Manajemen Perusahaan Koperasi. Erlangga. Jakarta.

[4] Hariyanto, Bambang. (2008). Sistem Manajemen Basis Data: Pemodelan, Perancangan, dan Terapannya. Bandung: Informatika. Hlm.195-196.

[5] Ian Sommerville. 2003. Software Engineering (Rekayasa Perangkat Lunak)/Ian Sommerville; alih bahasa, Dra.Yuhilza Hanum M.Eng, ; Hilarius Wibi Hardani. Ed.6, Erlangga, Jakarta.

[6] Jogiyanto H.M. 1999. Analisis dan Disain Sistem Informasi. Andi.Yogyakarta. 